\title{
Evaluation of waist circumference to predict general obesity and arterial hypertension in women in Greater Metropolitan Belo Horizonte, Brazil
}

Gustavo Velásquez-M eléndez 1 Gilberto Kac 2 Joaquim Gonçal ves Valente 3,4 Roberta Tavares 1 Cibele Queiroz da Silva 5 Emerson Silami Garcia 6

\author{
Avaliação da capacidade preditiva da \\ circunferência da cintura para obesidade global \\ e hipertensão arterial em mulheres residentes \\ na Região Metropolitana de Belo Horizonte, Brasil
}

1 Departamento de Enfermagem Materno Infantil e Saúde Pública, Escola de Enfermagem, Universidade Federal de Minas Gerais. Av. Alfredo Balena 190, Belo Horizonte, MG 30130-100, Brasil. guveme@lcc.ufmg.br 2 Departamento de Nutrição Social e Aplicada, Instituto de Nutrição Josué de Castro, Universidade Federal do Rio de Janeiro. Av. Brigadeiro Trompowsky s/n, Bloco J, Rio de Janeiro, RJ 21941-590, Brasil.

3 Departamento de Epidemiologia e Métodos Quantitativos em Saúde, Escola Nacional de Saúde Pública, Fundação Oswaldo Cruz. Rua Leopoldo Bulhões 1480, Rio de Janeiro, RJ, 21041-210, Brasil.

4 Instituto de Medicina Social, Universidade do Estado do Rio de Janeiro. Rua São Francisco Xavier 524, Bloco D, Rio de Janeiro, RJ 20559-900, Brasil.

5 Instituto de Ciências Exatas, Universidade Federal de Minas Gerais. Av. Antônio Carlos 6627 . Belo Horizonte, MG 31270-901, Brasil.

6 Escola de Educação Física, Universidade Federal de Minas Gerais. Av. Antônio Carlos 6627, Belo Horizonte, MG 31270-901, Brasil.

\begin{abstract}
This study examined the capacity of waist circumference (WC) to identify subjects with overweight (BMI $\geq 25)$ and obesity ( $B M I \geq 30)$, in agreement with internationally recommended levels of action. Data were obtained from 791 women, 15-59 years ol d. After identifying overweight and obesi ty according to WC values, sensiti vity and specificity were calculated to verify whether WC could be a good risk predictor for hypertension. Associations were tested by linear regression and logi stic regression, controlling for confounding. WC cut-off points of $80 \mathrm{~cm}$ and $88 \mathrm{~cm}$ correctly identified $89.8 \%$ and $88.5 \%$ of women with overweight and obesity, respectively. Abdominal obesity ( $W C \geq 88 \mathrm{~cm}$ ) was statistically associated with hypertension in the multivariate analysis (OR $=2.88 ; 95 \% \mathrm{Cl}: 1.77-4.67)$. Hypertensi on was identified with a sensitivity of $63.8 \%$ and $42.8 \%$, and with a specificity of $68.0 \%$ and $83.3 \%$, for WC $\geq 80$ and $\geq 88$, respectively. The proposed cut-off points for abdominal obesity can potentially distinguish individuals at risk for future obesity, but has only moderate power to predict individuals with high blood pressure.
\end{abstract}

Key words Obesity; Women's Health; Hip; Hypertension; Body Mass Index

Resumo Avaliou-sea capacidade que a Circunferência da Cintura (CC) tem em identificar valores de IMC $\geq 25$ (sobrepeso) e $\geq 30$ (obesi dade) a partir de níveis de ação recomendados internaci onalmente. Setecentas e noventa e uma mulheres entre 15-59 anos foram recrutadas. Foram cal culadas a sensi bilidade e a especi fi ci dade no diagnóstico de sobrepeso e obesi dade e a sensi bilidade e especificidade na predição da hipertensão, a partir de valores de CC. As associações foram testadas por análise de regressão linear e regressão logística controlando para o efeito de fatores de confusão. A CC $\geq 80$ e $\geq 88 \mathrm{~cm}$ discriminou corretamente $89,8 \%$ de mul heres com I MC $\geq$ 25 e $88,5 \%$ com IMC $\geq 30$. A obesi dade abdominal (CC $\geq 88 \mathrm{~cm})$ esteve associada si gnificativamente com a hi pertensão na análise multivariada (OR =2,88, IC 95\%: 1,77-4,67). A hipertensão foi identificada com sensi bilidade de 63,8 e $42,8 \%$ e especifici dade de 68,0 e $83,3 \%$ para CC $\geq 80$ e $\geq 88$, respectivamente. A obesi dade abdominal nos pontos de corte propostos pode discriminar adequadamente indi víduos em risco de se tornarem obesos, no entanto, apresenta um poder apenas moderado para discriminar indivíduos com níveis pressóricos altos.

Palavras-chave Obesidade; Saúde da Mulher; Quadril; Hi pertensão; Índice de Massa Corporal 


\section{Introduction}

In recent decades a major increase has been reported in the prevalence of overweight and obesity in different regions of Brazil, both in men and women and from all social classes. This phenomenon has been detected by various population surveys conducted in the last 25 years (INAN, 1991; Monteiro \& Conde, 1999). The mechanisms underlying this trend are still unknown, although researchers have raised hypotheses concerning the consumption of denser diets and a reduction in the level of energy expenditure.

Various cross-sectional and longitudinal studies have shown that accumulated abdominal fat is associated with increased risk of noncommunicable diseases, especially cardiovascular diseases, coronary arteriosclerosis, and overall mortality, in addition to insulin-resistance syndrome, hypertriglyceridemia, and increased low density lipoprotein levels (Folson et al., 2000; Lapidus et al., 1984).

Diagnosis of overweight and obesity using simple indicators like body mass index (BMI) is extensively consolidated in the literature (WHO, 1998). Despite its limitations, this indicator has been systematically utilized in epidemiological studies for the diagnosis and evaluation of secular trends in overweight/ obesity in children and adults (Monteiro et al., 2000; WHO, 1990). Due to the seriousness of the problem, there is an intensive search for even simpler, more precise, and more sensitive methods to adequateIy diagnose excess body fat, associating it with key health problems, to ultimately foster the implementation of preventive and intervention measures. Although there are sophisticated methods like computed imaging techniques for the precise measurement of body fat, such methods are still scarcely feasible in epidemiological studies.

In the 1990s, Han et al. (1995) proposed that waist circumference (WC) $\geq 80 \mathrm{~cm}$ (action level 1 ) and WC $\geq 88 \mathrm{~cm}$ (action level 2) be used as cut-off points to identify women with overweight and obesity, respectively. The action levels were also felt to be indicative for recommending individual weight control and health promotion in women (Han et al., 1995; Lean et al., 1995). According to a different view, these levels might reflect only the populations that generated them and were thus probably not applicable to the diversity of the overall Brazilian population (Gus et al., 1998; Okosun et al., 2000; Velásquez-Meléndez et al., 1999).

The objective of this study was thus to evaluate the capacity of WC to distinguish individ- uals with overweight and obesity, in addition to testing its association with arterial hypertension using cut-off points proposed in the literature.

\section{Methodology}

The current study adopted a cross-sectional design and was conducted at a Municipal Health Center in the city of Belo Horizonte, Minas Gerais, Brazil. The Health Center was chosen because it provides daily out-patient care covering residents from the entire Greater Belo Horizonte Metropolitan Area. Participants were female volunteers in apparent good general health, with no chronic or acute metabolic or infectious complaints, who were treated at the various departments of the Health Center, with the objective of obtaining a wide range of age and BMI values. Data were gathered from January to July 2000 , and the initial sample consisted of 827 women from 14 to 65 years of age. The sample size was calculated to obtain accurate estimates of the probability of overweight/ obesity, given a set of covariables (Flack \& Eudey, 1993). For the current analysis, we excluded women under 15 and over 59 years of age $(n=$ 36), producing a final sample of 791 individuals.

A questionnaire containing standardized questions on various aspects characterizing the sample (current and past disease, use of medication, life style, schooling, smoking, demographic and socioeconomic factors, and obstetric history) was applied by trained interviewers.

Weight and height were measured with the individuals barefoot and without excess clothing or accessories. Height was measured to the closest $0.1 \mathrm{~cm}$, with a stiff tape measure placed vertically on a flat wall, with the subject standing erect and head in the Frankfurt plane (Lohman et al., 1988). Weight was measured with a digital scale (Model PL 150, Filizzola Ltd., Brazil), to the closest $0.1 \mathrm{~kg}$. These measurements were then used to calculate the body mass index (BMI = weight $(\mathrm{kg}) /$ height 2$)$. WC was measured with the subject standing, midway between the last rib and the upper edge of the iliac crest, and hip circumference $(\mathrm{HC})$ was measured at the greater gluteal curvature. Both measurements were taken with a stiff fiberglass tape, to the closest $0.1 \mathrm{~cm}$. All anthropometric measurements were taken by previously trained anthropometrists, and repeated three times, using the mean value.

Blood pressure was measured by trained interviewers according to criteria proposed by 
the Joint National Committee (JNC, 1997) with aneroid sphygmomanometers, using the indirect auscultatory method, with the arm resting at the level of the precordium, using Korotkoff phases I and IV to read the systolic and diastolic blood pressure, respectively. Hypertension was defined according to the following criteria: systolic blood pressure $\geq 140 \mathrm{mmH}$ or diastolic pressure $\geq 90 \mathrm{mmHg}$ (JNC, 1997).

Initial statistical analysis involved the description of target variables with means and standard deviations. Sensitivity, specificity, and positive and negative predictive values and their $95 \%$ confidence intervals were calculated to evaluate whether WC appropriately identified individuals with overweight $(B M I \geq 25)$ and obesity (BMI $\geq 30$ ). Bivariate and partial linear regression analysis was used to test possible associations between systolic blood pressure (SBP), diastolic blood pressure (DBP), and anthropometric variables (WC, BMI, and waistto-hips ratio - WHR). Logistic regression, with the different WC categories (level $1 \geq 80$ and level $2 \geq 88 \mathrm{~cm}$ ) as independent variables, was used to evaluate the effect of the different WC action levels on hypertension. Both linear regression (partial coefficients) and logistic regression used age, schooling, smoking, alcohol consumption, and physical activity as control variables. Age was calculated from the date of birth and included in the model as a continuous variable (minimum 15 and maximum 59), as was education (minimum 0 and maximum 21), measured as complete years of schooling. Life style variables were included in dichotomous form: current smoking (yes or no), alcohol consumption at least once a week (yes or no), and practicing a sport (yes or no).

Sensitivity was defined as the proportion of hypertensive individuals correctly identified by the proposed WC cut-off points and specificity as the proportion of non-hypertensive individuals correctly identified by values below the proposed WC cut-off points.

All statistical analyses used SPSS version 8.0 (SPSS Incorporation, 1997). Results were considered statistically significant with $p$ values $<0.05$. The current project was approved by the research ethics committee at Universidade Federal de M inas Gerais. Written consent was obtained from all study participants.

\section{Results}

Table 1 shows mean values and standard deviations for some anthropometric measurements and blood pressure levels in the sample.
WC values $\geq 80 \mathrm{~cm}$ (action level 1 ) correctly identified $89.8 \%$ (95\% Cl: 85.5-93.1) of women with overweight (BMI $\geq 25$ ), while WC $\geq 88 \mathrm{~cm}$ (action level 2) correctly identified $88.5 \%$ (95\% $\mathrm{Cl}: 85.5-91.1)$ of women with obesity (BMI $\geq 30)$ (Table 2).

We observed both bivariate and multivariate statistically significant positive correlations adjusted for age, schooling, smoking, alcohol consumption, and physical activity between WC, BMI, and WHR and SBP and DBP (Table 3). The weakest correlation coefficients were observed between WHR and both blood pressure levels.

Figure 1 shows SBP and DBP data for previously defined WC categories. A clear increase was observed in SBP and DBP with increasing WC. Meanwhile, a slight drop was observed in mean SBP in the $78-81.9 \mathrm{~cm}$ bracket and in

Table 1

Mean and standard deviation for selected variables in a sample of women. Belo Horizonte, Minas Gerais, Brazil, 2000

\begin{tabular}{lcc}
\hline Variables & Mean $(\mathbf{n}=\mathbf{7 9 1})$ & Standard deviation \\
\hline Age (years) & 30.95 & 10.53 \\
Weight $(\mathrm{kg})$ & 60.35 & 12.50 \\
Height $(\mathrm{cm})$ & 158.49 & 6.13 \\
Body mass index $\left(\mathrm{kg} / \mathrm{m}^{2}\right)$ & 24.04 & 4.85 \\
Waist circumference $(\mathrm{cm})$ & 78.60 & 13.39 \\
Hips circumference $(\mathrm{cm})$ & 97.83 & 9.50 \\
Waist-to-hips ratio & 0.80 & 0.10 \\
Systolic arterial pressure $(\mathrm{mmHg})$ & 116.26 & 15.66 \\
Diastolic arterial pressure $(\mathrm{mmHg})$ & 76.55 & 12.80 \\
\hline
\end{tabular}

Table 2

False positives, false negatives, sensitivity, specificity, and $95 \%$ confidence intervals in the identification of individuals with overweight $\left(\mathrm{BMI} \geq 25 \mathrm{~kg} / \mathrm{m}^{2}\right)$ and obesity $\left(\mathrm{BMI} \geq 30 \mathrm{~kg} / \mathrm{m}^{2}\right)$ based on $\mathrm{WC} \geq 80$ and $\geq 88 \mathrm{~cm}$, respectively. Belo Horizonte, Minas Gerais, Brazil, 2000.

\begin{tabular}{lcc}
\hline Prediction & \multicolumn{2}{c}{ Waist Circumference (cm) } \\
& 280 & $\geq 88$ \\
\hline Overall total $(\mathrm{n})$ & 298 & 169 \\
Total hypertensives $(\mathrm{n})$ & 27 & 59 \\
False positives $(\mathrm{n})$ & 60 & 95 \\
False negatives $(\mathrm{n})$ & 27 & 3 \\
Sensitivity $(\%, 95 \% \mathrm{Cl})$ & $89.8(85.5-93.1)$ & $88.5(85.5-91.1)$ \\
Specificity $(\%, 95 \% \mathrm{Cl})$ & $96.1(89.0-99.1)$ & $86.6(83.9-89.1)$ \\
\hline
\end{tabular}


Table 3

Crude and adjusted correlation coefficients comparing systolic blood pressure (SBP) and diastolic blood pressure (DBP) with waist circumference (WC), body mass index (BMI), and waist-to-hips ratio (WHR). Belo Horizonte, Minas Gerais, Brazil, 2000.

\begin{tabular}{llcccc}
\hline \multirow{2}{*}{$\begin{array}{l}\text { Anthropometric } \\
\text { variables }\end{array}$} & \multirow{2}{*}{ no. } & \multicolumn{2}{c}{ SBP } & \multicolumn{2}{c}{ DBP } \\
& & Crude & Adjusted1 & Crude & Adjusted1 \\
WC $(\mathrm{cm})$ & 789 & 0.377 & 0.264 & 0.393 & 0.272 \\
BMI $\left(\mathrm{kg} / \mathrm{m}^{2}\right)$ & 790 & 0.414 & 0.319 & 0.413 & 0.308 \\
WHR & 790 & 0.236 & 0.115 & 0.273 & 0.152 \\
\end{tabular}

1 Adjusted for age, schooling, smoking, alcohol consumption, and physical activity. 2 All correlations with $p<0.001$. mean DBP in the $94-104.9 \mathrm{~cm}$ bracket as compared to the next highest.

Prevalence of hypertension was $17.4 \%$. An association was observed between abdominal obesity and hypertension. Table 4 shows crude odds ratios and odds ratios adjusted for age, schooling, smoking, alcohol consumption, and physical activity. Abdominal obesity (WC $=80$ $87 \mathrm{~cm})$ was associated significantly with hypertension (OR $=2.57 ; 95 \% \mathrm{Cl}: 1.53-4.32$ ), while this association was slightly attenuated when adjusted for other variables $(\mathrm{OR}=1.76 ; 95 \% \mathrm{Cl}$ : 1.01-3.07). When abdominal obesity was de-

Figure 1

Mean values and $95 \%$ confidence intervals for systolic blood pressure (a) and diastolic blood pressure (b)

in different waist circumference categories. Belo Horizonte, 2000.

Figure $1 \mathrm{a}$

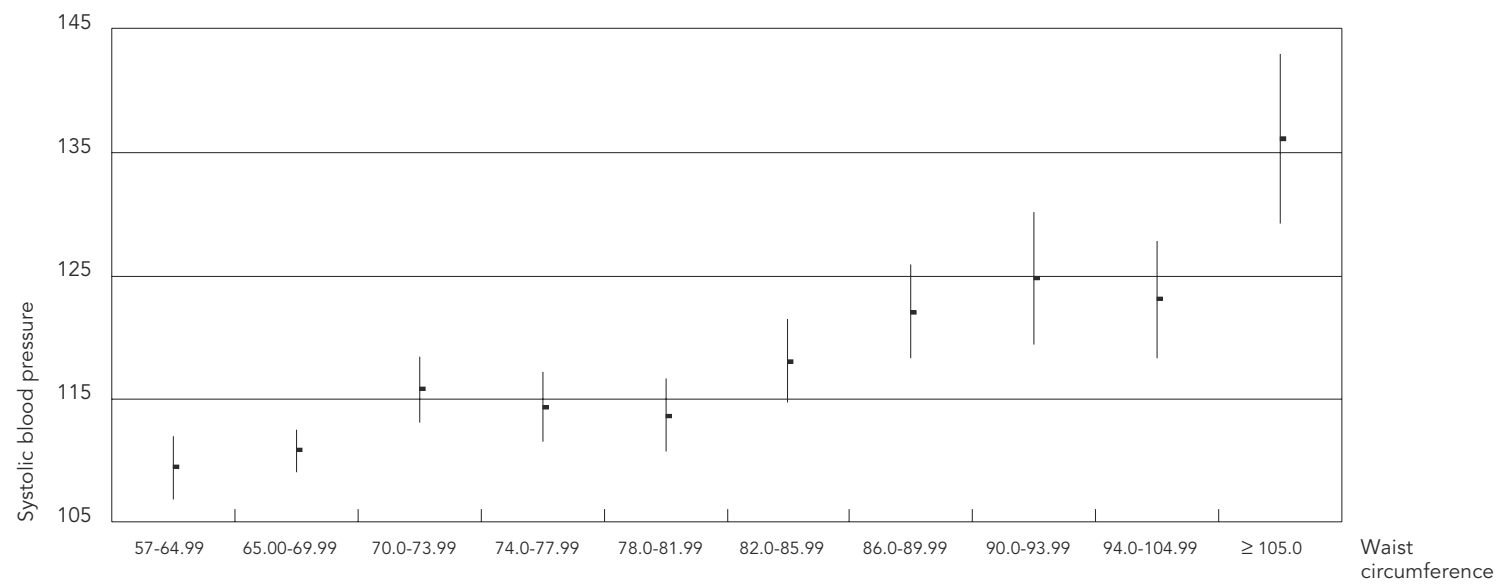

Figure $1 b$

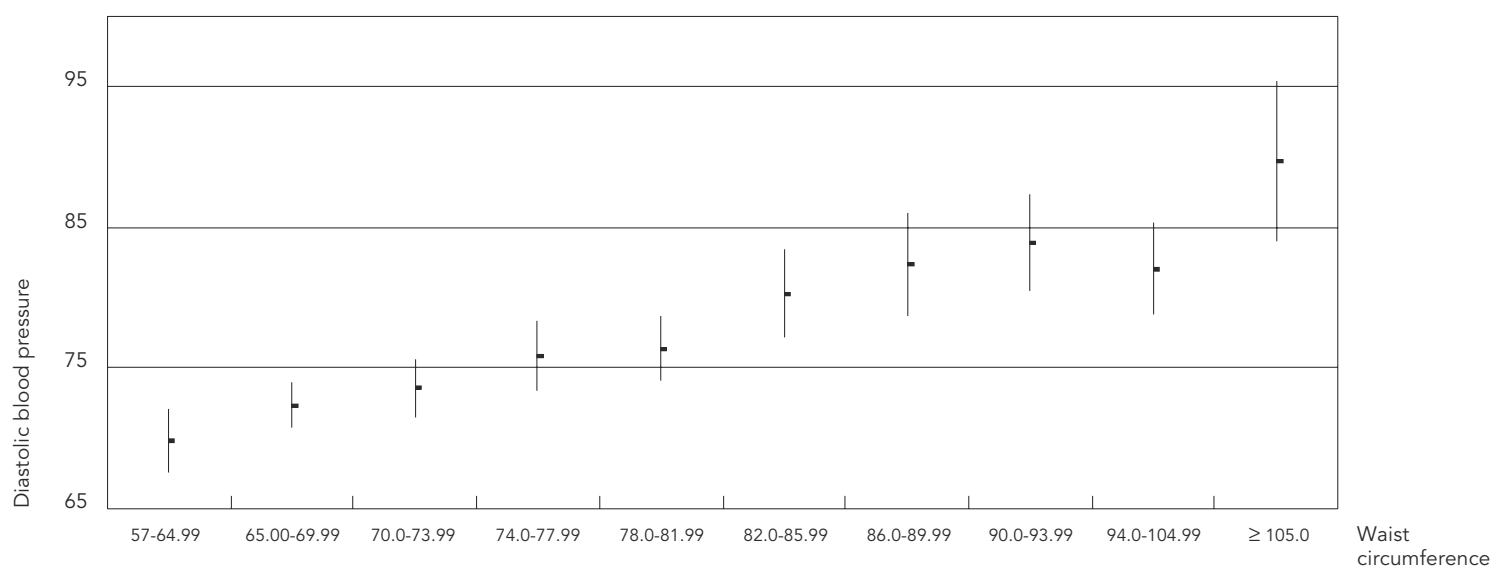


fined as WC $\geq 88 \mathrm{~cm}$, the association with hypertension was also statistically significant according to both bivariate analysis $(O R=4.75$; 95\% $\mathrm{Cl}: 3.08-7.31$ ) and adjusted analysis (OR = 2.88; $95 \% \mathrm{Cl}:$ 1.77-4.67).

Table 5 shows the predictive capacity (positive and negative predictive values) for two WC levels in relation to hypertension. Sensitivity in detecting hypertension was moderate for action level 1 (63.8\%; $95 \% \mathrm{Cl}: 55.1-71.7)$ and low for action level 2 (42.8\%; 95\% Cl: 34.5-54.5), respectively. Specificity was lower for action level 1 (68.0\%; $95 \% \mathrm{Cl}: 64.2-71.5$ ) as compared to action level 2 (83.3\%; $95 \% \mathrm{Cl}: 80.2-86.0)$. In relation to predictive capacity, the positive predictive values were low and similar for both levels. Negative predictive values were high and were also similar for both levels.

\section{Discussion}

Recent Brazilian and international research has called attention to the secular increase in the prevalence of overweight in various modern societies currently in transition (WHO, 1998). This increase has led to great concern among governments and international public health agencies.

A study by Vague (1956) was the first to differentiate the risk of abnormal regional fat deposits, identifying the risk of abdominal fat accumulation. Recent data show that waist circumference is adequately correlated with fat located in the abdominal region (Despres et al., 1991; Lemieux et al., 1996; Pouliot et al., 1994), which in turn is associated with various health problems (Folson et al., 1990; Han et al., 1998). This measurement was recently identified as the best indicator for evaluating the risk of cardiovascular diseases in epidemiological studies (Mollarius \& Seidell, 1998). However, there is still no consensus concerning the definition of cutoff points for abdominal adiposity to adequately identify the risk of cardiovascular diseases.

The data presented in this study support and strengthen the validity of using WC to identify overweight and obesity, with the advantage of being a simple and easy measurement. Waist circumference sensitivity, specificity, and predictive values proved satisfactory for diagnosing overweight and obesity at the levels proposed in the literature. However, it is important to exercise caution in using these findings, since in a US population of white, black, and Hispanic women, the WC values corresponding to overweight and obesity varied considerably, ranging from 80 to $90 \mathrm{~cm}$,
Table 4

Crude and adjusted odds ratios (OR) and 95\% confidence intervals $(95 \% \mathrm{Cl})$ for hypertension and two waist circumference action levels. Belo Horizonte, Minas Gerais, Brazil, 2000.

\begin{tabular}{lcccc}
\hline Waist circumference (cm) & \multicolumn{3}{c}{ Hypertension } & \multicolumn{2}{c}{ Adjusted1 } \\
& OR & $95 \% \mathrm{Cl}$ & OR & $95 \% \mathrm{Cl}$ \\
\hline$<80$ & 1.00 & - & 1.00 & - \\
80 to 87 & 2.57 & $1.53-4.32$ & 1.76 & $1.01-3.07$ \\
$\geq 88$ & 4.75 & $3.08-7.31$ & 2.88 & $1.77-4.67$ \\
\hline
\end{tabular}

1 Adjusted for age, schooling, smoking, alcohol consumption, and physical activity.

Table 5

Sensitivity, specificity, and positive and negative prediction for hypertension according to waist circumference (WC) action levels. Belo Horizonte, Minas Gerais, Brazil, 2000

\begin{tabular}{lcccc}
\hline \multirow{2}{*}{ Prediction } & \multicolumn{2}{c}{ WC $\geq 80 \mathrm{~cm}$} & \multicolumn{2}{c}{ WC $\geq 88 \mathrm{~cm}$} \\
& $\%$ & $95 \% \mathrm{Cl}$ & $\%$ & $95 \% \mathrm{Cl}$ \\
\hline Sensitivity & 63.8 & $55.1-71.7$ & 42.8 & $34.5-54.5$ \\
Specificity & 68.0 & $64.2-71.5$ & 83.3 & $80.2-86.0$ \\
Positive predictive value & 29.6 & $24.6-35.2$ & 35.1 & $28.0-42.9$ \\
Negative predictive value & 89.9 & $86.8-92.3$ & 87.3 & $84.4-89.8$ \\
\hline
\end{tabular}

which can lead to a major reduction in the precision of estimates (Okosun et al., 2000).

In this study, WC, BMI, and WHR showed a positive correlation with blood pressure. It was interesting to note that WC showed a correlation quite similar to that of BMI, while the correlation was weaker for WHR, confirming results from previous studies (Mollarius \& Seidell, 1998; Pouilot et al., 1994). The odds ratio for hypertension after adjusting for covariables was 2.88 for women with $W C \geq 88 \mathrm{~cm}$. The group of women with intermediate WC levels showed an excess risk of $76 \%$ as compared to women with WC less than $80 \mathrm{~cm}$. However, the positive predictive value of WC for hypertension can be considered low. Sensitivity was moderate for action level 1 and low for level 2 .

Two similar population-based studies have been conducted in Brazil. In one, hypertension was associated equally with abdominal obesity, WHR, and overweight (Gus et al., 1998). In the other, a WHR of 0.80 adequately differentiated women at risk of hypertension (Pereira et al., 1999). 
Some limitations to this study should be identified. First, the research was conducted with volunteers and non-probabilistic sampling, a factor that could limit extrapolation of the findings. Second, it only presents data for women.

In general, waist circumference with recommended cut-off points (Han et al., 1995; WHO, 1998) presents adequate power to differentiate individuals with overweight and obesity, with the advantage of not using mathematical formulas or ratios to define it, like BMI and WHR. Although WC was significantly associated with hypertension in the current study, the WC cut-off points evaluated here ( 80 and $88 \mathrm{~cm}$ ) showed moderate and low sensitivity,

\section{Acknowledgments}

We wish to thank the Office of the Dean of Research at Universidade Federal de Minas Gerais and the Brazilian National Research Council - CNPq (Grant No. 300721/94-3) for funding this project. respectively, and low positive predictive values for hypertension, which would lead to a reasonable number of individuals inadequately identified for risk of hypertension, thus limiting the use of these cut-off points for proper, low-cost screening of health risks in population groups.

In short, we conclude that further studies are needed, simultaneously evaluating sets of cut-off points in various Brazilian population groups from different age brackets and both sexes, especially investigating the balance between sensitivity and specificity, allowing for the identification of more appropriate cut-off points for the overall national population.

\section{References}

DESPRES, J. P.; PRUD'HOM ME, D.; POULIOT, M. C.; TREM BLAY, A. \& BOU CHARD, C., 1991. Estimation of deep abdominal adipose tissue anthropometric measurements in men. American Journal of Clinical Nutrition, 54:471-477.

FLACK, V. F. \& EUDEY, T. L., 1993. Sample size determinations using logistic regression with pilot data. Statistics in Medicine, 12:1079-1084.

FOLSON, A. R.; KUSHI, L. H.; ANDERSON, K. E.; MINK, P. J.; OLSON, J. E.; HONG, C. P.; SELLERS, T. A.; LAZOVICH, D. \& PRINEAS, R. J., 2000. Associations of general abdominal obesity with multiple health outcomes in older women: The lowa Women's Health Study. Archives of Internal Medicine, 160:2117-2128.

FOLSON, A. R.; PRINEAS, R. J.; KAYE, A. S. \& MUNGER, R., 1990. Incidence of hypertension and stroke in relation to body fat distribution and other risk factors in older women. Stroke, 21:701-706.

GUS, M.; M OREIRA, L. B.; PIMENTEL, M.; GLEISENER, A. L.; MORAES, R. S. \& FUCHS, F. D., 1998. Associação entre diferentes indicadores de obesidade e prevalência de hipertensão arterial. Arquivos Brasileiros de Cardiologia, 70:111-114. 
HAN, T. S.; FESKENS, E. J.; LEAN, M. E. \& SEIDELL, J. C., 1998. Associations of body composition with type 2 diabetes mellitus. Diabetes in Medicine, 15:129-135.

HAN, T. S.; VAN LEER, E. M.; SEIDELL, J. C. \& LEAN, M. E., 1995. Waist circumference action levels in the identification of cardiovascular risk factors: Prevalence study in a random sample. BMJ, 311: 1401-1405.

JNC (Joint National Committee), 1997. The sixth report of the Joint National Committee on prevention, detection, evaluation, and treatment of high blood pressure. Archives of Internal Medicine, 157:2413-2445.

INAN (Instituto Nacional de Alimentação e Nutrição), 1991. Pesquisa Nacional sobre Saúde e Nutrição. Condi ções Nutricionais da População Brasileira: Adultos e Idosos. Brasília: INAN/Ministério da Saúde.

LAPIDUS, L.; BENGTSSON, C.; LARSSON, B.; PENNERT, K.; RYBO, E. \& SJOSTROM , L., 1984. Distribution of adipose tissue and risk of cardiovascular disease and death: A 12-year follow-up of participants in the study of women in Gothenburg, Sweden. BMJ, 289:1261-1263.

LEAN, M. E.; HAN, T. S. \& MORRISON, C. E., 1995. Waist circumference as a measure for indicating need for weight management. BMJ, 311:158-161.

LEMIEUX, S.; PRUD'HOMME, D.; BOUCHARD, C.; TREMBLAY, C. \& DESPRÉS, J. P., 1996. A single threshold value of waist girth identifies normalweight and overweight subjects with excess visceral adipose tissue. American Journal of Clinical Nutrition, 64:685-693.

LOHMAN, T. G.; ROCHE, A. F. \& MARTORELL, R., 1988. Anthropometric Standardization Reference Manual. Champaign: Human Kinetics Books.

MOLARIUS, A. \& SEIDELL, J. C., 1998. Selection of anthropometric indicators for classification of abdominal fatness - A critical review. International Journal of Obesity, 22:719-727.

MONTEIRO, C. A. \& CONDE, W. L., 1999. A tendência secular da obesidade segundo estratos sociais: Nordeste e Sudeste do Brasil, 1975-1989-1997. Arquivos Brasilei ros de Endocrinol ogia e Metabologia, 43:186-194.
MONTEIRO, P. O. A.; VICTORA, C. G.; BARROS, C. B. \& TOMASI, E., 2000. Diagnóstico de sobrepeso em adolescentes: Estudo do desempenho de diferentes critérios para o Índice de Massa Corporal. Revista de Saúde Pública, 34:506-513.

OKOSUN, I. S.; ROTIMINI, C. N.; FORRESTER, T. E.; FRASE, H.; OSOTIMEHIN, B.; MUNA, W. F. \& OOPER, R. S., 2000. Predictive value of abdominal obesity cut-off points for hypertension in Blacks from West African and Caribbean island nations. International Journal of Obesity, 24:180-186.

PEREIRA, R. A.; SICHIERI, R. \& M ARINS, V. M., 1999. Razão cintura/ quadril como preditor de hipertensão arterial. Cadernos de Saúde Pública, 15: 333-344.

POULIOT, M. C.; DESPRES, J. P.; LEMIEUX, S.; MOORJANI, S.; BOUCHARD, C.; TREMBLAY, A.; NADEAU, A. \& LUPIEN, P. J., 1994. Waist circumference and abdominal sagittal diameter: Best simple anthropometric indexes of abdominal visceral adipose tissue accumulation and related cardiovascular risk in men and women. American Journal of Cardiology, 73:460-468.

VAGUE, J., 1956. The degree of masculine differentiation of obesity: A factor determining predisposition to diabetes, arteriosclerosis, gout, and uric calculous disease. Journal of Clinical Nutrition, 4:20-34.

VELASQUEZ-MELENDEZ, G.; MARTINS, I. S.; CERVATO, A. M.; FÓRNES, N. S.; MARUCCI, M. F. N. \& COELHO, L. T., 1999. Relationship between stature, overweight and central obesity in the adult population in São Paulo, Brazil. International Journal of Obesity, 23:639-644.

WHO (World Health Organization), 1990. Diet, Nutrition, and the Prevention of Chronic Diseases. WHO Technical Report Series 797. Geneva: WHO.

WHO (World Health Organization), 1998. Preventing and Managing the Global Epidemic. Report of a WHO Consultation on Obesity. Geneva: WHO.

Submitted on 20 March 2001

Final version resubmitted on 12 September 2001

Approved on 21 December 2001 